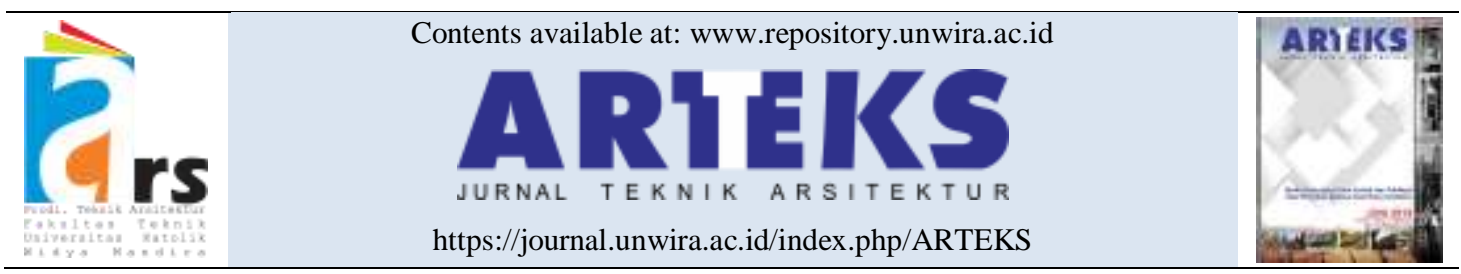

Research paper

doi: $10.30822 /$ arteks.v6i2.679

\title{
Co-living space: The shared living behavior of the millenial generation in Indonesia
}

\author{
Isrina Indah, Prabu Wardono*
}

Department of Design, Faculty of Arts and Design, Institut Teknologi Bandung

Jl. Ganesha no. 10, Lb. Siliwangi, Coblong, Bandung, Indonesia

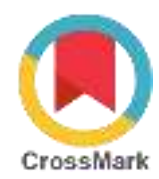

\begin{tabular}{|c|c|}
\hline ARTICLE INFO & ABSTRACT \\
\hline $\begin{array}{l}\text { Article history: } \\
\text { Received September } 26,2020 \\
\text { Received in revised form Nov. } 13,2020 \\
\text { Accepted January } 12,2021 \\
\text { Available online August } 01,2021\end{array}$ & $\begin{array}{l}\text { The continuous improvement in the growth rate of urbanization in } \\
\text { Indonesia is causing an increased need for work, limited residential } \\
\text { land, and high prices for residential development in urban areas. } \\
\text { This phenomenon has an impact on the low occupancy rate for the } \\
\text { millennial generation and this makes developers offer co-living }\end{array}$ \\
\hline $\begin{array}{l}\text { *Corresponding author: Prabu Wardono } \\
\text { Department of Design, Faculty of Arts and } \\
\text { Design, Institut Teknologi Bandung } \\
\text { Email: pwardono@ yahoo.com } \\
\text { ORCID: https://orcid.org/0000-0002-3751- } \\
7914\end{array}$ & $\begin{array}{l}\text { space which is considered capable of solving the problem of } \\
\text { accommodation and its use as a living space is becoming } \\
\text { increasingly popular in recent times. Therefore, this study aimed to } \\
\text { identify the factors influencing the formation of habitual occupancy } \\
\text { among millennials in the co-living space of Indonesia. The process } \\
\text { involved using a survey method with online questionnaires to collect } \\
\text { data from the study population which consisted of the millennial } \\
\text { generation with a sample size of } 190 \text { respondents. The data obtained } \\
\text { were processed using exploratory multivariant statistics to show the } \\
\text { relationship between the latent variables used in forming habitual } \\
\text { behavior in shared living. The results showed } 10 \text { factors which } \\
\text { constitute the living behavior in co-living space and they include } \\
\text { public facilities, social, place attachment, feeling of satisfaction, } \\
\text { environment, intrinsic, extrinsic, group development, economy, and } \\
\text { workspace availability. }\end{array}$ \\
\hline
\end{tabular}

\section{Introduction}

The age structure of the Indonesian society is expected to change between 2020 and 2030 due to the decrease in the ratio of non-productive ages which include those lesser than 15 years and above 65 years to the productive or working age range of 15-64 years old (Santoni, Yongsie, and Devi 2020). The country currently has a $70 \%$ workforce which is dominated by the millennial generation (generation $\mathrm{Y}$ ) while the rest 30\% constitutes the unproductive category. Consequently, the increase observed in the workforce has also caused an increment in the migration of the millennial generation to urban cities (Badan Pusat Statistik 2018).

The continuous increase in the population of urban areas has limited the availability of residential land (Pramudito, Praptantya, and Nasir 2019; Sanjaya and Tobing 2019), thereby, causing a hike in the price of residential development and, subsequently, difficulties for the millennial generation to have adequate accommodation. This means the prices of properties and land are on the increase and this has also led to low occupancy rates due to the inability to meet the financial requirement to own or rent a house.

Residential development is, however, expected to focus on the social factors in order to reflect several interactions occurring in the society to reduce loneliness even though the need to solve the housing problem is extremely urgent (Subroto 2019; Widodo 2019). According to Corcoran and Marshal (2017) in Hoppenbrouwer (2019), there is less interaction between communities even though people live close to each other and this 
causes loneliness and less connection (Hoppenbrouwer 2019). Fauziyyah and Ampuni (2018) also reported that social skills mediated by loneliness and lower social skills contribute negatively to depression and higher form of loneliness also has the ability to increase the tendency of depression (Fauziyyah and Ampuni 2018).

Therefore, one of the methods considered to be effective in curbing the problem of urbanization, high occupancy prices, and feelings of loneliness is the use of shared living such as coliving space as an alternative residence (SPACE10, Anton, and Irene 2018).

Co-living space has been defined as the novelty of a boarding house for travelers to provide mutual support in collaboration with the community (Johnson 2016). The concept was further described by Ataman and Dino (2019) to be a catalyst for social interaction through the introduction of a way to live together through more efficient sharing, use of resources, and space (Ataman and Dino 2019). It also provides opportunities for students and workers to reduce rental costs and daily expenses.

The availability of shared facilities such as lounge areas, communal kitchens, workspaces, fitness facilities, bathrooms, laundry, aims to create social activities for the users (Osborne 2018). Several studies have been conducted by researchers from different fields on the concept and this includes Best Practices for Urban Coliving (Osborne 2018) in Brooklyn, Manhattan Outside London, and Central London using a questionnaire from One Shared House 2030 (SPACE10, Anton, and Irene 2018).

Another study on Collective Residential Spaces in Sustainability Development: Turkish Housing Units within Co-Living Understanding focused on the adjustment of physical aspects which involves using private and public areas, economic aspects, as well as the social interaction and co-living management aspects (Ataman and Dino 2019).

The concept was also described to include the sharing facilities and collective use of space to ensure interaction between users and strengthen their contributions in co-living as indicated by Hoppenbrouwer (2019) in "The Community Effects of Co-living Exploring opportunities for Dutch developer-led co-living in fostering community building among residents" (Hoppenbrouwer 2019).
This research was, therefore, conducted to explore the factors required to understand living behavior in co-living space among millennials in Indonesia with the focus on the social, economic, environmental, motivational, and physical factors as well as the facilities of the housing. This means several experiments were required on different coliving space models from different parts of the world in order to determine the appropriate arrangement and also foster demographics and culture in the selected city (Green 2017).

According to the Profiles of Indonesia's Millennial Generation (Statistics, 2018), the term "millennial" was first coined by William Strauss and Neil in their book Millennials Rising: The Next Great Generation (2000). Moreover, Elwood Carlson (2008) in Profiles of Indonesian Millennial Generation (Badan Pusat Statistik 2018) classified the millennial generation as those born between 1983 and 2001 while Karl Mannheim (1923) in Profiles of Indonesian Millennial Generation (Badan Pusat Statistik 2018) used 1980 to 2000. Putra (2017) in The Theoretical Review: The Theory of Generation Differences also explained the differences in the ranges of birth year in relation to generation $\mathrm{Y}$ as discovered by several researchers from different countries, and the millennial generation was described as those born between 1980 and 2000 (Y. S. Putra 2017).

These explanations were the rationale used in this research to identify the problem related to forming factors and understanding the living behavior in the co-living space among millennials in Indonesia with the hope to discover new factors apart from the existing ones.

\section{Method}

This research aimed to identify the forming factors and understand the living behavior in the co-living space among millennials in Indonesia which are thought to be closely related to social, economic, environmental, motivation, facilities, and physical aspects. Therefore, the question developed to be answered is "what are the forming factors influencing living behavior in coliving space among the millennial generation?

The research was conducted using a survey method through the application of an online questionnaire while the data were processed and analyzed with the multivariant statistical method 
of Exploratory Factor Analysis (EFA) using the variables found in previous research related to coliving space.

The survey was conducted by distributing questionnaires to 190 respondents online. The study population includes the Indonesian people belonging to Generation $\mathrm{Y}$ or millennial generation which include those born from 19812000 with a minimum age of 20 years and maximum age of 39 years and living in any region of the country while the samples used in this research were selected based on the Nonprobability Sampling technique in the form of purposive sampling.

The dimensions measured include 1. Social, 2. Economy, 3. Environment, 4. Motivation, 5. Conditions of public facilities, 6. Conditions of private facilities, and 7. Physical conditions of occupancy. They were used as the basic variables to determine the living behavior of millennials in choosing co-living space. Meanwhile, some questions related to demographic information and respondent characteristics were also included in the questionnaire.

The research instrument was arranged based on a Likert scale using a scale of 1,2,3,4 and 5 with 1 used to represent strongly agree, 2 for agree, 3 for neutral, 4 for disagree, and 5 for strongly disagree. The questionnaire was designed to have 51 question items which were analyzed for reliability, validity, and factor using the EFA method in SPSS program. The validity test showed 15 question items were invalid because their Corrected Item-Total Correlation value was $<0.3$ and minus after which a Cronbach's Alpha value of 0.903 was recorded for the reliability test after the invalid items have been removed. This means 36 question items were confirmed to be valid and reliable in achieving the objectives of this research.

\section{Result and discussion}

The data on the respondents' demographics and characteristics were processed using descriptive statistics while their responses were analyzed through factor analysis using the EFA method in SPSS program.
Living behavior-forming factors of millennials in co-living space

The demographics data of the respondents showed majority represented by $70 \%$ were female, $63.7 \%$ were born in 1991-1995 and aged 29-25 years, and $54.2 \%$ were from outside Jakarta and Bandung.

It was also discovered that 42 respondents are students in the age range of 24-20 years and $45.3 \%$ currently live in boarding houses. Moreover, $80 \%$ have heard about co-living space even though $57.9 \%$ have never lived in this type of housing. The data also showed $78.4 \%$ want a single male or female occupant and $75.8 \%$ prefer a roommate to reduce rental costs. However, $79.5 \%$ believe the optimal number of occupants in co-living should be $<8$ people while $46.8 \%$ select new occupants algorithmically - according to the procedure. Furthermore, $62.6 \%$ prefer the urban area as the location for the co-living space and $41.6 \%$ responded that fish species are allowed to be kept as pets while $8.4 \%$ indicated animals were not allowed in the apartment.

Factor analysis

This analysis was used to show the relationship between a number of latent variables used to measure living behavior in shared living to establish relevant constructs.

Kaiser Meyer Olkin measure of sampling (KMO) test: The data obtained from the questionnaire was observed to have met the appropriate requirements due to its ability to show Kaiser Meyer Olkin Measure of Sampling (KMO) value of 0.782 which is above 0.5 as shown in table 1. Moreover, the Barlett's Test of Sphericity was found to be 2470,374 with a specification value of 0,000 and this means it also meets the requirements because the significance value is below $0.05(5 \%)$.

Table 1. KMO value and Barlett's test

\begin{tabular}{|c|c|c|}
\hline \multicolumn{3}{|c|}{ KMO and Bartlett's test } \\
\hline \multicolumn{2}{|c|}{$\begin{array}{l}\text { Kaiser-Meyer-Olkin Measure of } \\
\text { Sampling Adequacy. }\end{array}$} & ,782 \\
\hline $\begin{array}{l}\text { Bartlett's Test of } \\
\text { Sphericity }\end{array}$ & $\begin{array}{l}\text { Approx. Chi- } \\
\text { Square }\end{array}$ & 2470,374 \\
\hline & & 595 \\
\hline
\end{tabular}

Anti- image matrices test:

During the process of testing the Measures of Sampling Adequacy (MSA) value, 36 items were used and the value is required to be $>0.5$ but 1 item had $<0.5$. Therefore, a re-analysis was 
conducted by removing the invalid items and the results of the 35 items that meet the requirements are presented in table 2 .

Table 2. MSA value

\begin{tabular}{|c|c|c|}
\hline No & Variable & MSA \\
\hline 1 & Social 1 (There is social cohesion) & $.753^{\mathrm{a}}$ \\
\hline 2 & $\begin{array}{l}\text { Social } 2 \text { (Combating loneliness, social } \\
\text { isolation, and disconnection) }\end{array}$ & $.845^{\mathrm{a}}$ \\
\hline 3 & Social 3 (Strong sense of community) & $.837^{\mathrm{a}}$ \\
\hline 4 & $\begin{array}{l}\text { Social } 4 \text { (Sense of belonging to the } \\
\text { occupancy) }\end{array}$ & $.794^{\mathrm{a}}$ \\
\hline 5 & $\begin{array}{l}\text { Social } 5 \text { (The presence of spontaneity } \\
\text { in social interactions) }\end{array}$ & $.745^{\mathrm{a}}$ \\
\hline 6 & $\begin{array}{l}\text { Social } 6 \text { (The efforts to establish } \\
\text { social interactions) }\end{array}$ & $.800^{\mathrm{a}}$ \\
\hline 7 & $\begin{array}{l}\text { Economy } 2 \text { (Share of the amount of } \\
\text { energy used in the occupancy) }\end{array}$ & $.748^{\mathrm{a}}$ \\
\hline 8 & Economy 3 (affordability) & $.667^{\mathrm{a}}$ \\
\hline 9 & $\begin{array}{l}\text { Environment } 1 \text { (Reducing the use of } \\
\text { energy sources) }\end{array}$ & $.760^{\mathrm{a}}$ \\
\hline 10 & Environment 2 (strategic location) & $.631^{\mathrm{a}}$ \\
\hline 11 & $\begin{array}{l}\text { Environment } 3 \text { (Reduced costs due to } \\
\text { shared use) }\end{array}$ & $.750^{\mathrm{a}}$ \\
\hline 12 & $\begin{array}{l}\text { Motivation } 1 \text { (There is a strong sense } \\
\text { of community) }\end{array}$ & $.829^{\mathrm{a}}$ \\
\hline 13 & $\begin{array}{l}\text { Motivation } 2 \text { (New life experiences } \\
\text { and diversity) }\end{array}$ & $.820^{\mathrm{a}}$ \\
\hline 14 & $\begin{array}{l}\text { Motivation } 3 \text { (Sharing a sense of } \\
\text { responsibility) }\end{array}$ & $.854^{\mathrm{a}}$ \\
\hline 15 & $\begin{array}{l}\text { Motivation } 4 \text { (equitability to all } \\
\text { residents) }\end{array}$ & $.810^{\mathrm{a}}$ \\
\hline 16 & $\begin{array}{l}\text { Motivation } 5 \text { (Having a new } \\
\text { community environment) }\end{array}$ & $.877^{\mathrm{a}}$ \\
\hline 17 & $\begin{array}{l}\text { Motivation } 6 \text { (Sharing of facilities and } \\
\text { equipment in the occupancy) }\end{array}$ & $.861^{\mathrm{a}}$ \\
\hline 18 & $\begin{array}{l}\text { Motivation } 7 \text { (Potential for arguments } \\
\text { against fellow residents) }\end{array}$ & $.611^{\mathrm{a}}$ \\
\hline 19 & $\begin{array}{l}\text { Public Facility } 1 \text { (Bedrooms not more } \\
\text { than } 2 \text { people) }\end{array}$ & $.602^{\mathrm{a}}$ \\
\hline 20 & $\begin{array}{l}\text { Public Facility } 2 \text { (Use of shared } \\
\text { kitchen) }\end{array}$ & $.796^{\mathrm{a}}$ \\
\hline 21 & $\begin{array}{l}\text { Public Facility } 3 \text { (Use of shared } \\
\text { workspace) }\end{array}$ & $.580^{\mathrm{a}}$ \\
\hline 22 & $\begin{array}{l}\text { Public Facility } 4 \text { (Use of shared } \\
\text { laundry room) }\end{array}$ & $.785^{\mathrm{a}}$ \\
\hline 23 & Public Facility 5 (Use of shared gym) & $.814^{\mathrm{a}}$ \\
\hline 24 & $\begin{array}{l}\text { Public Facility } 6 \text { (Use of shared } \\
\text { lounge area together) }\end{array}$ & $.813^{\mathrm{a}}$ \\
\hline 25 & $\begin{array}{l}\text { Public Facility } 7 \text { (Use of shared } \\
\text { outdoor facilities) }\end{array}$ & $.866^{\mathrm{a}}$ \\
\hline 26 & $\begin{array}{l}\text { Public Facility } 8 \text { (Use of shared } \\
\text { swimming pool) }\end{array}$ & $.793^{\mathrm{a}}$ \\
\hline 27 & $\begin{array}{l}\text { Private Facility } 1 \text { (Residential design } \\
\text { like a private apartment) }\end{array}$ & $.675^{\mathrm{a}}$ \\
\hline 28 & $\begin{array}{l}\text { Private Facilities } 2 \text { (Design occupancy } \\
\text { equipped with furniture/full furnished) }\end{array}$ & $.644^{\mathrm{a}}$ \\
\hline 29 & $\begin{array}{l}\text { Physical Occupancy } 1 \text { (Preference is } \\
\text { choosing site and cluster type } \\
\text { occupancy) }\end{array}$ & $.823^{\mathrm{a}}$ \\
\hline
\end{tabular}

\begin{tabular}{lll}
\hline No & Variable & MSA \\
\hline 30 & $\begin{array}{l}\text { Physical Occupancy 2 (Preference for } \\
\text { choosing occupancy with parking } \\
\text { lots) }\end{array}$ & $.826^{\mathrm{a}}$ \\
\hline 31 & $\begin{array}{l}\text { Physical Occupancy 3 (Preference for } \\
\text { choosing occupancy related to design } \\
\text { concepts) }\end{array}$ & $.589^{\mathrm{a}}$ \\
\hline 32 & $\begin{array}{l}\text { Physical Occupancy 4 (Preference for } \\
\text { choosing occupancy with adequate }\end{array}$ & $.698^{\mathrm{a}}$ \\
& lighting and ventilation) \\
\hline 33 & $\begin{array}{l}\text { Physical Occupancy 5 (Preference } \\
\text { choosing an occupancy with a garden) }\end{array}$ & $.593^{\mathrm{a}}$ \\
\hline 34 & $\begin{array}{l}\text { Physical Occupancy 6 (Preference for } \\
\text { choosing occupancy adjacent to the } \\
\text { family) }\end{array}$ & $.774^{\mathrm{a}}$ \\
\hline 35 & $\begin{array}{l}\text { Physical Occupancy 7 (Preference } \\
\text { choosing a large area of occupancy in } \\
\text { private and public areas) }\end{array}$ & $.741^{\mathrm{a}}$ \\
\hline & &
\end{tabular}

Factor extraction:

This involved the application of the Principal Components Analysis (PCA) to determine the factors with extraction value $>0.5$ and the results are presented in table 3 .

Table 3. Extraction result variable

\begin{tabular}{|c|c|c|}
\hline \multicolumn{3}{|c|}{ Communalities } \\
\hline & Initial & Extraction \\
\hline SOCIAL 1 & 1,000 & ,628 \\
\hline SOCIAL 2 & 1,000 & 516 \\
\hline SOCIAL 3 & 1,000 & 650 \\
\hline SOCIAL 4 & 1,000 & 612 \\
\hline SOCIAL 5 & 1,000 & ,493 \\
\hline SOCIAL 6 & 1,000 & .579 \\
\hline ECONOMY 2 & 1,000 & 464 \\
\hline ECONOMY 3 & 1,000 & 597 \\
\hline ENVIRONMENT 1 & 1,000 & 682 \\
\hline ENVIRONMENT 2 & 1,000 & 612 \\
\hline ENVIRONMENT 3 & 1,000 & 733 \\
\hline MOTIVATION 1 & 1,000 & ,734 \\
\hline MOTIVATION 2 & 1,000 & 679 \\
\hline MOTIVATION 3 & 1,000 & 690 \\
\hline MOTIVATION 4 & 1,000 & 711 \\
\hline MOTIVATION 5 & 1,000 & 565 \\
\hline MOTIVATION 6 & 1,000 & 574 \\
\hline MOTIVATION 7 & 1,000 & 646 \\
\hline PUBLIC FACILITY 1 & 1,000 & .563 \\
\hline PUBLIC FACILITY 2 & 1,000 & 694 \\
\hline PUBLIC FACILITY 3 & 1,000 & 644 \\
\hline PUBLIC FACILITY 4 & 1,000 & 696 \\
\hline PUBLIC FACILITY 5 & 1,000 &, 731 \\
\hline PUBLIC FACILITY 6 & 1,000 & 678 \\
\hline PUBLIC FACILITY 7 & 1,000 & 771 \\
\hline PUBLIC FACILITY 8 & 1,000 & 769 \\
\hline PRIVATE FACILITY 1 & 1,000 & .584 \\
\hline PRIVATE FACILITY 2 & 1,000 & 648 \\
\hline PHYSICAL & 1,000 & 630 \\
\hline OCCUPANCY 1 & & \\
\hline PHYSICAL & 1,000 & ,588 \\
\hline OCCUPANCY 2 & & \\
\hline PHYSICAL & 1,000 & 641 \\
\hline OCCUPANCY 3 & & \\
\hline PHYSICAL & 1,000 & ,643 \\
\hline OCCUPANCY 4 & & \\
\hline
\end{tabular}




\begin{tabular}{lcl}
\hline \multicolumn{3}{c}{ Communalities } \\
\hline & Initial & Extraction \\
\hline $\begin{array}{l}\text { PHYSICAL } \\
\text { OCCUPANCY 5 }\end{array}$ & 1,000 &, 710 \\
$\begin{array}{l}\text { PHYSICAL } \\
\text { OCCUPANCY 6 } \\
\quad \text { PHYSICAL } \\
\quad \text { OCCUPANCY 7 }\end{array}$ & 1,000 &, 583 \\
\hline \multicolumn{2}{c}{ Extraction method: Principal component analysis. } \\
\hline
\end{tabular}

Table 4. Extraction result variable

\begin{tabular}{|c|c|c|c|c|c|c|c|c|c|}
\hline \multicolumn{10}{|c|}{ Total variance explained } \\
\hline \multirow[b]{2}{*}{ Component } & \multicolumn{3}{|c|}{ Initial eigenvalues } & \multicolumn{3}{|c|}{ Extraction sums of squared loadings } & \multicolumn{3}{|c|}{ Rotation Sums of squared loadings } \\
\hline & Total & $\begin{array}{l}\% \text { of } \\
\text { Variance }\end{array}$ & $\begin{array}{l}\text { Cumulative } \\
\%\end{array}$ & Total & $\begin{array}{l}\% \text { of } \\
\text { variance }\end{array}$ & $\begin{array}{l}\text { Cumulative } \\
\%\end{array}$ & Total & $\begin{array}{l}\% \text { of } \\
\text { variance }\end{array}$ & $\begin{array}{l}\text { Cumulative } \\
\%\end{array}$ \\
\hline 1 & 7,124 & 20,355 & 20,355 & 7,124 & 20,355 & 20,355 & 3,960 & 11,315 & 11,315 \\
\hline 2 & 3,341 & 9,546 & 29,901 & 3,341 & 9,546 & 29,901 & 3,369 & 9,627 & 20,942 \\
\hline 3 & 2,223 & 6,350 & 36,252 & 2,223 & 6,350 & 36,252 & 2,505 & 7,158 & 28,100 \\
\hline 4 & 2,019 & 5,770 & 42,021 & 2,019 & 5,770 & 42,021 & 2,235 & 6,386 & 34,486 \\
\hline 5 & 1,590 & 4,543 & 46,565 & 1,590 & 4,543 & 46,565 & 2,058 & 5,880 & 40,366 \\
\hline 6 & 1,425 & 4,073 & 50,637 & 1,425 & 4,073 & 50,637 & 2,007 & 5,733 & 46,099 \\
\hline 7 & 1,322 & 3,777 & 54,414 & 1,322 & 3,777 & 54,414 & 1,840 & 5,256 & 51,355 \\
\hline 8 & 1,211 & 3,461 & 57,875 & 1,211 & 3,461 & 57,875 & 1,548 & 4,422 & 55,777 \\
\hline 9 & 1,062 & 3,033 & 60,909 & 1,062 & 3,033 & 60,909 & 1,471 & 4,202 & 59,979 \\
\hline 10 & 1,001 & 2,860 & 63,768 & 1,001 & 2,860 & 63,768 & 1,326 & 3,789 & 63,768 \\
\hline 11 & ,963 & 2,751 & 66,520 & & & & & & \\
\hline 12 & -927 & 2,650 & 69,169 & & & & & & \\
\hline 13 & ,861 & 2,461 & 71,630 & & & & & & \\
\hline 14 & , 848 & 2,424 & 74,054 & & & & & & \\
\hline 15 & ,743 & 2,122 & 76,176 & & & & & & \\
\hline 16 & ,683 & 1,953 & 78,129 & & & & & & \\
\hline 17 & 679 & 1,940 & 80,069 & & & & & & \\
\hline 18 & ,630 & 1,801 & 81,870 & & & & & & \\
\hline 19 & ,607 & 1,733 & 83,603 & & & & & & \\
\hline 20 & ,585 & 1,671 & 85,273 & & & & & & \\
\hline 21 & ,562 & 1,606 & 86,879 & & & & & & \\
\hline 22 & ,533 & 1,524 & 88,403 & & & & & & \\
\hline 23 & ,499 & 1,427 & 89,830 & & & & & & \\
\hline 24 & ,434 & 1,239 & 91,069 & & & & & & \\
\hline 25 & ,421 & 1,204 & 92,273 & & & & & & \\
\hline 26 & ,395 & 1,129 & 93,402 & & & & & & \\
\hline 27 & ,346 & ,989 & 94,391 & & & & & & \\
\hline 28 & ,333 & ,951 & 95,342 & & & & & & \\
\hline 29 & ,298 & ,850 & 96,193 & & & & & & \\
\hline 30 & ,287 & ,819 & 97,011 & & & & & & \\
\hline 31 & , 253 & ,722 & 97,734 & & & & & & \\
\hline 32 & ,224 & ,640 & 98,374 & & & & & & \\
\hline 33 & , 219 & ,626 & 98,999 & & & & & & \\
\hline 34 & , 185 & ,528 & 99,527 & & & & & & \\
\hline 35 &, 165 & ,473 & 100,000 & & & & & & \\
\hline
\end{tabular}

Scree plot:

The scree plot graph shows the number of factors formed, except in the variant table, by
Extraction results:

The extraction results in the total variance explained table showed that the 35 variables are all correlated to the co-living space among the millennial generation as observed from the initial eigenvalue column. Meanwhile, the extraction sums of squared loadings column showed a large number of variations or factors formed as indicated in the initial eigenvalue section, provided the value is $>1$. These variables were, therefore, used to form 10 new factors as shown in table 4. 


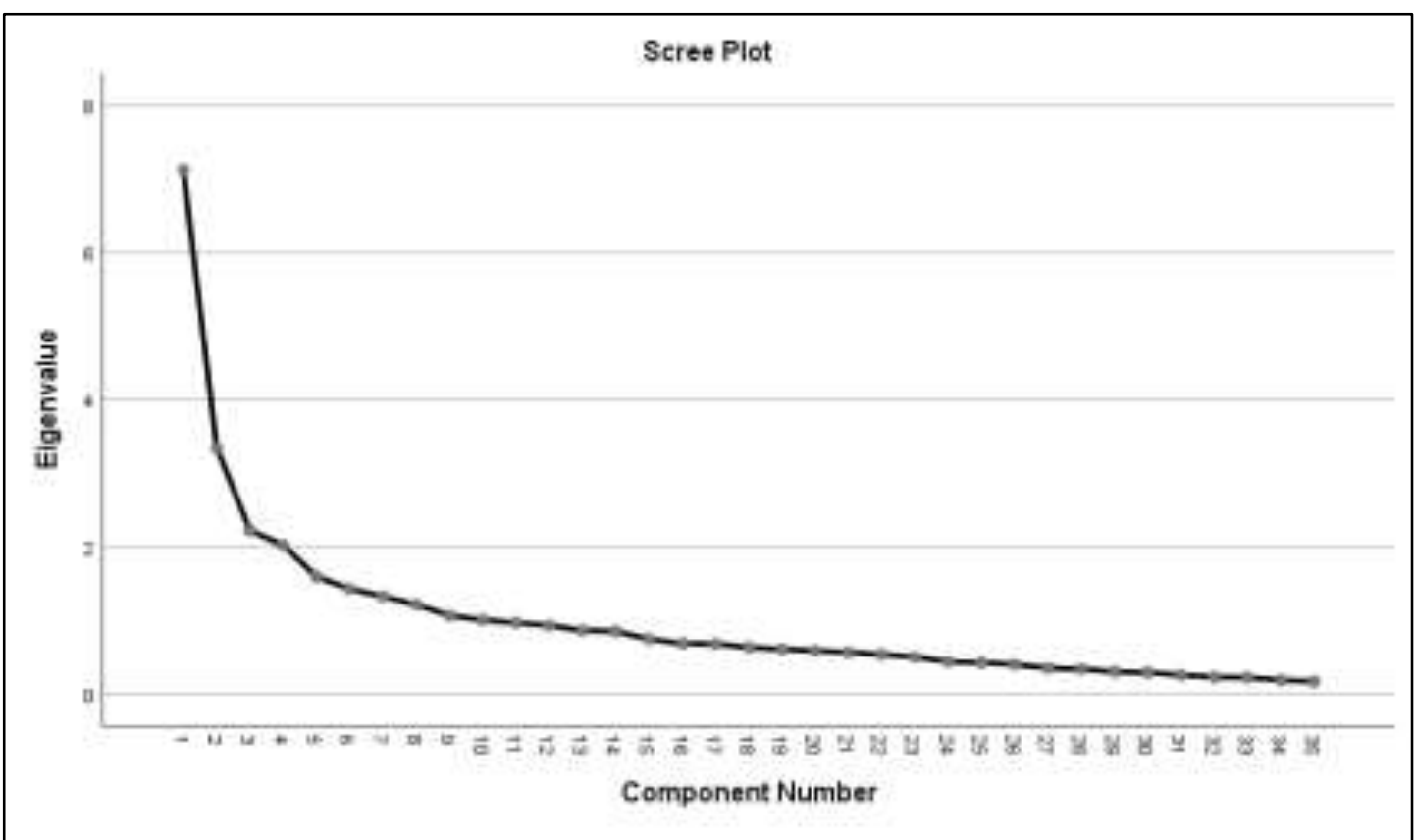

Figure 1. Scree plot of variable extraction results

Component matrix:

The component matrix table shows the correlation value or the relationship between the variables and the factors to be formed with the extracted variables presented in table 5 .

Table 5. Extraction result variable

\begin{tabular}{|c|c|c|c|c|c|c|c|c|c|c|}
\hline \multirow{2}{*}{ Component matrix ${ }^{a}$} & \multicolumn{10}{|c|}{ Component } \\
\hline & 1 & 1 & 1 & 1 & 1 & 1 & 1 & 1 & 1 & 1 \\
\hline PUBLIC FACILITY 7 & ,681 & 362 &,- 311 &, 033 &, 164 &, 010 & ,041 &,- 064 &,- 137 &,- 163 \\
\hline MOTIVATION 3 & ,672 &,- 214 & ,031 &,- 075 &,- 029 &,- 034 &,- 202 &,- 264 & ,090 &, 255 \\
\hline MOTIVATION 5 & ,631 &,- 284 &, 035 & ,241 &,- 064 &,- 020 &,- 020 &,- 108 &,- 085 & 046 \\
\hline PUBLIC FACILITY 6 &, 603 & ,289 &,- 417 &, 067 &, 018 &,- 148 &,- 088 &,- 044 &,- 092 & ,109 \\
\hline MOTIVATION 4 &, 576 & ,222 &, 063 &,- 397 &,- 196 & 075 &,- 097 &,- 214 &, 185 &, 186 \\
\hline MOTIVATION 2 &, 574 &,- 349 &,- 137 & 226 &,- 129 &,- 113 &,- 162 &,- 141 &,- 253 &, 134 \\
\hline PUBLIC FACILITY 2 &, 548 & 232 &,- 401 &,- 179 &,- 052 &,- 077 &, 128 &, 345 &, 056 &,- 009 \\
\hline SOCIAL 3 &, 529 &,- 506 &, 060 &, 064 &,- 085 &,- 185 &, 251 &, 038 &,- 024 &,- 009 \\
\hline PUBLIC FACILITY 8 &, 528 & ,313 &,- 328 &, 156 &, 057 & 237 &, 344 &,- 256 &,- 050 &,- 119 \\
\hline SOCIAL 5 &, 250 &,- 514 &,- 058 & ,087 & 102 & 169 &,- 100 &, 119 & ,208 &,- 222 \\
\hline SOCIAL 2 & ,404 &,- 456 & ,004 &, 161 &,- 002 &,- 016 &, 217 &, 212 &,- 018 &,- 164 \\
\hline SOCIAL 1 & ,419 &,- 450 &, 160 &, 104 &, 060 &,- 077 &, 232 &, 367 & ,088 & ,087 \\
\hline PHYSICAL OCCUPANCY 6 &, 376 & 415 &, 200 &,- 028 &,- 276 &,- 257 &,- 139 &,- 035 &, 238 &,- 098 \\
\hline PUBLIC FACILITY 4 &, 475 & ,339 &,- 499 &, 058 & ,076 & ,006 &, 025 & ,275 &, 022 &, 139 \\
\hline ENVIRONMENT2 & ,209 & ,191 & ,441 &,- 423 &,- 087 & ,102 & ,246 &,- 056 &,- 274 & ,046 \\
\hline PHYSICAL OCCUPANCY 3 &, 162 & ,208 &, 433 &, 517 &,- 047 & ,259 & ,193 &, 009 &,- 019 & ,099 \\
\hline ENVIRONMENT1 & , 436 &,- 155 &, 132 &,- 486 &,- 057 &, 318 &,- 157 &, 193 &,- 143 &,- 169 \\
\hline ECONOM 3 & ,307 & ,097 &, 120 &,- 418 &, 185 &,- 327 & ,211 & ,201 &,- 187 & ,207 \\
\hline PUBLIC FACILITY 1 & ,398 & ,176 & ,261 &, 027 &, 530 &,- 096 & ,044 &,- 081 &,- 160 &,- 033 \\
\hline
\end{tabular}




\begin{tabular}{|c|c|c|c|c|c|c|c|c|c|c|}
\hline \multirow{2}{*}{ Component matrix ${ }^{a}$} & \multicolumn{10}{|c|}{ Component } \\
\hline & 1 & 1 & 1 & 1 & 1 & 1 & 1 & 1 & 1 & 1 \\
\hline MOTIVATION 7 &, 255 &,- 144 &, 169 &,- 048 &, 378 &, 463 &, 000 &,- 127 &, 270 & ,287 \\
\hline PHYSICAL OCCUPANCY 5 & 228 &, 189 &, 385 & ,381 &,- 280 &, 392 & 149 &,- 016 &,- 227 &, 151 \\
\hline SOCIAL 4 &, 402 &,- 350 &, 125 &,- 080 &,- 043 &,- 227 & 501 &,- 001 & 036 &,- 006 \\
\hline ECONOMY2 & 227 &,- 257 &,- 012 &,- 261 & ,220 &, 047 &,- 376 &, 163 &,- 243 &, 028 \\
\hline PUBLIC FACILITY 3 & 176 &, 115 &,- 189 & 424 &,- 201 & 153 &,- 167 &, 453 &, 013 &, 294 \\
\hline PUBLIC FACILITY 1 &, 190 & 273 & 247 &,- 223 & 212 & 279 & 053 &, 344 & 311 & 032 \\
\hline PHYSICAL OCCUPANCY 1 & ,392 &, 110 &, 234 & ,287 &, 081 &, 045 &,- 283 &, 186 &,- 021 &,- 451 \\
\hline Extraction method: Principal c & onent a & nalysis. ${ }^{a}$ & & & & & & & & \\
\hline
\end{tabular}

Rotated component matrix

The rotated component matrix is useful to ensure a variable falls into a factor group due to the non-arrangement of the variables at this stage.
This was determined by looking at the largest correlation value between the variables and the factors formed or the components and the results are indicated in table 6.

Table 6. Rotated component matrix

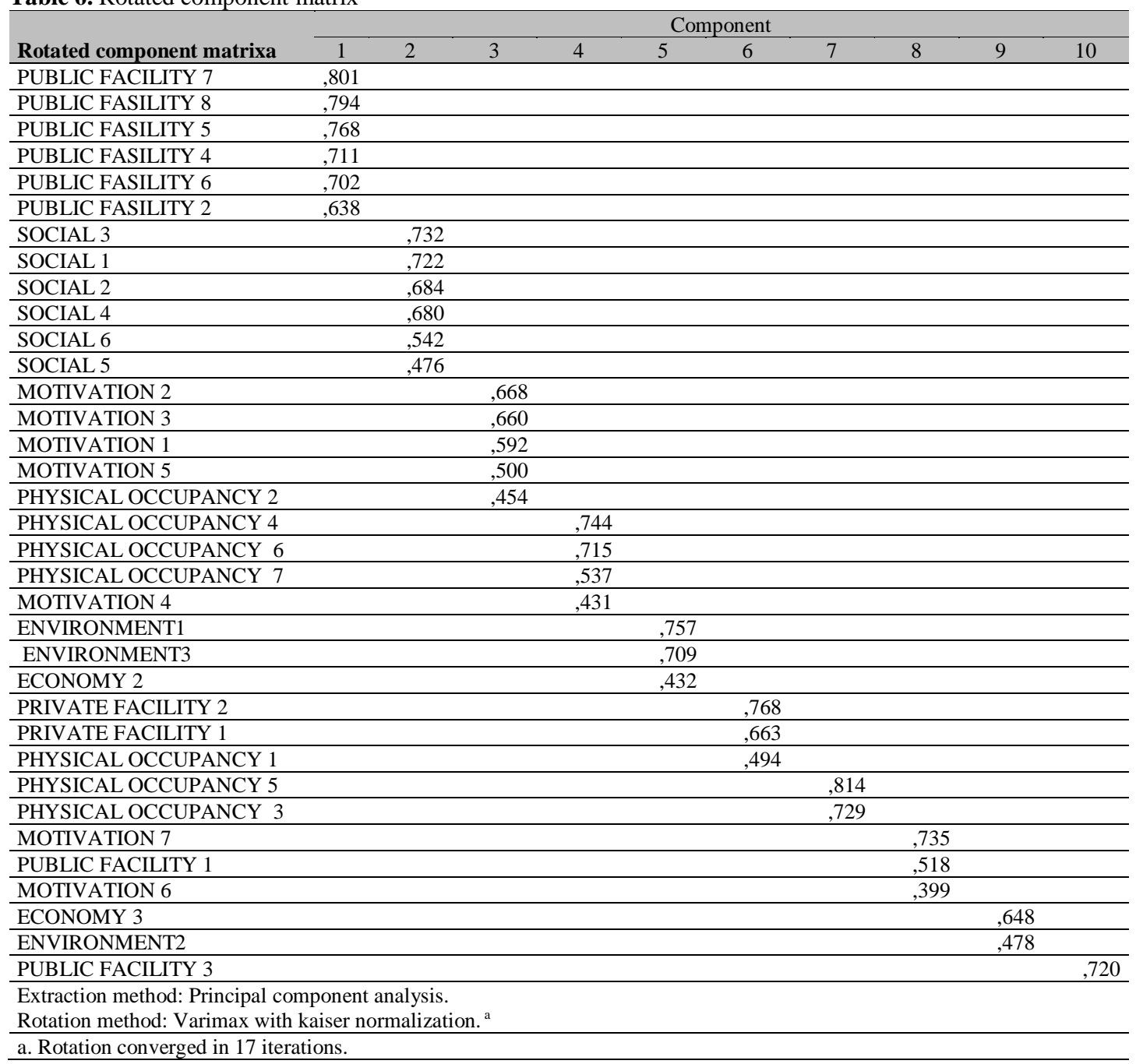

The results presented in the rotation showed the items included in each factor are as follows:
- Factor 1, there are 6 items;

- Factor 2, there are 6 items; 
- Factor 3, there are 5 items;

- Factor 4, there are 4 items;

- Factor 5, there are 3 items;

- Factor 6, there are 3 items;

- Factor 7, there are 2 items;

- Factor 8, there are 3 items;

- Factor 9, there are 2 items;

- Factor 10, there is 1 item.

Findings:

The data were processed using the factor analysis method and the 10 factors found to be determining the living behavior of co-living space for the millennial generation are described in the following table 7 .

Table 7. Findings

\begin{tabular}{|c|c|}
\hline Factor & Variable \\
\hline $\begin{array}{l}\text { 1. Public facility } \\
\text { factor }\end{array}$ & $\begin{array}{l}\text { 1. Public facilities 7: Use of } \\
\text { shared outdoor facilities; } \\
\text { 2. Public facilities } 8 \text { : Use of } \\
\text { shared swimming pools; } \\
\text { 3. Public facilities 5: Use of a } \\
\text { shared gym; } \\
\text { 4. Public facilities 4: Use of } \\
\text { shared laundry rooms; } \\
\text { 5. Public facilities 6: Use of } \\
\text { shared lounge area; } \\
\text { 6. Public facilities 2: Use of a } \\
\text { shared kitchen. }\end{array}$ \\
\hline 2. Social factor & $\begin{array}{l}\text { 1. Social Aspect 3: A strong } \\
\text { sense of community; } \\
\text { 2. Social Aspect 1: The existence } \\
\text { of social cohesion (bond } \\
\text { between residents); } \\
\text { 3. Social Aspect 2: Combating } \\
\text { loneliness, social isolation, and } \\
\text { disconnection; } \\
\text { 4. Social Aspect 4: There is an } \\
\text { attachment to co-living (sense } \\
\text { of belonging); } \\
\text { 5. Social Aspects 6: Joint } \\
\text { activities to build social } \\
\text { interactions; } \\
\text { 6. Social Aspect 5: There is } \\
\text { spontaneity in social } \\
\text { interactions. }\end{array}$ \\
\hline $\begin{array}{l}\text { 3. Place attachment } \\
\text { factor }\end{array}$ & $\begin{array}{l}\text { 1. Motivational Aspect 2: } \\
\text { Experience of a new lifestyle } \\
\text { and diversity; } \\
\text { 2. Motivation Aspect } 3 \text { : Sharing a } \\
\text { sense of responsibility; } \\
\text { 3. Motivation Aspect 1: A strong } \\
\text { sense of community; } \\
\text { 4. Motivational Aspect 5: Having } \\
\text { a new community } \\
\text { environment; } \\
\text { 5. Physical Occupancy Aspects } 2 \text { : } \\
\text { Preference in choosing } \\
\text { occupancy with parking lots. }\end{array}$ \\
\hline $\begin{array}{l}\text { 4. Feeling of } \\
\text { Satisfaction } \\
\text { Factor }\end{array}$ & $\begin{array}{l}\text { 1. Physical Occupancy Aspect 4: } \\
\text { Preference for choosing }\end{array}$ \\
\hline
\end{tabular}

\begin{tabular}{|c|c|}
\hline Factor & Variable \\
\hline & $\begin{array}{l}\text { occupancy with adequate } \\
\text { lighting and ventilation; } \\
\text { 2. Physical Occupancy Aspect 6: } \\
\text { Preference for choosing } \\
\text { occupancy adjacent to the } \\
\text { family; } \\
\text { 3. Physical Occupancy Aspect 7: } \\
\text { Preference for choosing } \\
\text { occupancy with a large space } \\
\text { in private and public areas; } \\
\text { 4.Motivation Aspect 4: Equality } \\
\text { for all occupants (equitability). }\end{array}$ \\
\hline $\begin{array}{l}\text { 5.Environment } \\
\text { Factor }\end{array}$ & $\begin{array}{l}\text { 1. Environment 1: Energy } \\
\text { resources, due to shared used } \\
\text { (community resources); } \\
\text { 2. Environment 3: Reduction of } \\
\text { ecological costs and } \\
\text { environmental damage due to } \\
\text { shared use; } \\
\text { 3. Economy 2: Distribution is } \\
\text { done evenly to each occupant } \\
\text { of the amount of energy used. }\end{array}$ \\
\hline 6. Intrinsic Factors & $\begin{array}{l}\text { 1. Private Facility 2: Design } \\
\text { occupancy equipped with } \\
\text { furniture/full furnished; } \\
\text { 2. Private Facility 1: Design } \\
\text { occupancy like a private } \\
\text { apartment; } \\
\text { 3. Physical Occupancy 1: } \\
\text { Preference is to choose the } \\
\text { type of occupancy site and } \\
\text { cluster. }\end{array}$ \\
\hline 7. Extrinsic Factors & $\begin{array}{l}\text { 1. Physical Occupancy 5: } \\
\text { Preference in choosing an } \\
\text { occupancy with a garden; } \\
\text { 2. Physical Occupancy 3: } \\
\text { Preference in choosing } \\
\text { occupancy related to the } \\
\text { architectural design concept of } \\
\text { a building. }\end{array}$ \\
\hline $\begin{array}{l}\text { 8. Group } \\
\text { Development } \\
\text { Factor }\end{array}$ & $\begin{array}{l}\text { 1. Motivation 7: Potential } \\
\text { argument between residents; } \\
\text { 2. Motivation 6: Sharing existing } \\
\text { facilities and equipment in } \\
\text { occupancy; } \\
\text { 3. Public 1: Bedrooms not more } \\
\text { than 2 people. } \\
\end{array}$ \\
\hline 9. Economy Factor & $\begin{array}{l}\text { 1. Economy Aspect 3: Affordable } \\
\text { prices (affordability); } \\
\text { 2. Environment Aspect 2: } \\
\text { Strategic location and close to } \\
\text { public transportation. }\end{array}$ \\
\hline $\begin{array}{l}\text { 10. Workspace } \\
\text { Availability Factor }\end{array}$ & $\begin{array}{l}\text { Public Aspect 3: Use of a shared } \\
\text { workspace. }\end{array}$ \\
\hline
\end{tabular}

The explanation of each of the factors indicated in the table is as follows:

Factor 1: Public facility

These are facilities which are collectively used with other residents and they have been discovered to be preferred by most of the 
millennial generation while selecting their choice for co-living. This was also clarified by William (2005) in Hoppenbrouwer (2019) that facilities and space to be shared in co-housing and co-living is considered one of the most important qualities due to its ability to reduce costs and increase social interaction (Williams 2005). This study found the facilities collectively used by users include the outdoor area, swimming pool, gym, laundry room, lounge area, and kitchen.

This is in line with the findings of previous studies that the use of shared space is one of the factors shaping the habit of living in a co-living space.

Factor 2: Social factor

1. The "strong sense of community" observed in this study is in line with the findings of Walker (2017), Hoppenbrouwer (2019), and Ataman and Dino (2019) which specifically showed that co-living aims to encourage a sense of community by providing shared and private living with mutual dependent on socialization and network (Walker 2017; Hoppenbrouwer 2019; Ataman and Dino 2019).

2. The "social cohesion or attachment between residents" factor is also in accordance with the findings of Hoppenbrouwer (2019) that showed two co-living behaviors related which include a high level of solidarity, thereby, ensuring there is no shame in seeking assistance from other residents and expecting same from them (Hoppenbrouwer 2019).

3. The "fighting loneliness, social isolation, and disconnection" fact was in line with the results of Walker (2017) that co-living is an opportunity for people to interact with each other and avoid social isolation and feelings of loneliness (Walker 2017).

4. The "attachment to co-living or sense of belonging" factor was also explained by Ataman and Dino (2019) to include the negotiations on the use of the place, length of time to use the place, and whoever is involved in the process are important aspects of coliving occupancy due to their ability to create peaceful conditions and provide an adequate sense of belonging to the residents (Ataman and Dino 2019).

5. The "joint activities to establish social interactions" factor was found to be the same with the explanation of Pretty and Ward (2001) in Williams' (2005) 'Designing Neighborhoods for Social Interaction: The
Case of Cohousing" that social interaction provides residents with adequate information on about fellow residents and their social structure (Williams 2005). This helps to build trust between residents, allows exchanges, and also creates social networks or connectedness and general rules/norms (Fix and Lesniak 2017; Hoppenbrouwer 2019).

6. The "spontaneity in social interactions" factor was also found to be similar to the results of Fix and Lesniak (2017).

These explanations, therefore, mean that the social factors found in this study are in line with the findings of previous research which related social interaction with the sense of community or togetherness due to its ability to provide information on the residents. This consequently leads to the formation of social structures to build trust as well as social networks and rules or norms between the residents.

Factor 3: Place attachment factor

Rubinstein and Parmelee (1992) in "Attachment to Place and the Representation of the Life Course by the Elderly" showed that the experiences and memories with the environment and the people living in it have the ability to provide a sense of security and intimacy as well as identity (Rubinstein and Parmelee 1992). It is, however, important to note that the collection of one's memories and feelings about a place is called a place attachment. It was used as the third factor and applied to determine the residents' ties with their occupancy in order to form a sense of togetherness in the community.

1. The "experience of a new lifestyle and diversity" has been previously reported by SPACE10, Anton, and Irene (2018) at Welcome to One Shared House 2030 and they found that respondents were willing to live with a diverse group of people with different backgrounds and ages (SPACE10 2017).

2. The "sharing a sense of responsibility" factor was also observed to have been explained by Ataman and Dino (2019) that residents have a stuff sharing system in co-living in which they have access to each other's unused items. This means the co-living environment provides an opportunity for residents to share a sense of responsibility for the use of goods (Ataman and Dino 2019).

3. The "strong sense of community" factor was observed to be the same as the one stated by Osborne (2018) to be a major factor 
motivating people to live in a co-living occupancy with the most important facilities found to be community kitchen, workspace, community manager, and sense of community (Osborne 2018).

4. The "having a new community environment" factor was in line with the findings of SPACE10, Anton, and Irene (2018) at Welcome to One Shared House 2030 that there are 3 main choices for residents to live in co-living and one of these is having a new environment outside work or lecture area (SPACE10, Anton, and Irene 2018).

5. The "preference for choosing occupancy with parking lots" factor was also explained by Najib, Yusof, and Osman (2011) in "Measuring Satisfaction with Student Housing Facilities" that the availability of parking space has the ability to provide comfort for residents (Ekananda and Marcillia 2019).

This, therefore, means the place attachment factor is in accordance with previous research which showed occupants' attachment to their environment as an indication of the emotional support they receive from their neighbors which leads them to bond with the environment.

\section{Factor 4: Feeling of satisfaction factor}

Fachrudin and Fachrudin (2014) in "Tenant Satisfaction in Boarding House and its Relationship to Renewal in Medan City, Indonesia" defined satisfaction as a feeling of enjoyment from occupancy in line with the needs or desires of buyers or tenants (Fachrudin and Fachrudin 2014). This factor was tagged "Feeling of satisfaction" due to its relation to the occupancy preferences desired by residents to create a feeling of satisfaction.

1. The "preference for choosing occupancy with adequate lighting and ventilation" factor was observed to be in line with the findings of Ekananda and Marcillia (2019) in the "Preference for physical attributes of occupancy generations $\mathrm{Y}$ and $\mathrm{Z}$ in Yogyakarta" that these generations want energy-efficiency which involves adequate openings to maximize natural light and ventilation (Ekananda and Marcillia 2019; Fachrudin and Fachrudin 2014; Thomsen and Eikemo 2010).

2. Nadiya (2017) also researched "preference for occupancy adjacent to the family" and found the selection of occupancy by Gen Y tends to be influenced by the location where their parents/family live (Nadiya 2017). This is associated with the fact that most of the students live with their parents and prefer to stay close them when they move from the house.

3. The "preference for choosing occupancy with a large space in private and public areas" factor was found to be in line with the findings of Ekananda and Marcillia (2019) that gen Y and $\mathrm{Z}$ prioritize private space for the family as the most important physical attribute (Thomsen and Eikemo 2010; Ekananda and Marcillia 2019).

4. The "equality for all residents or equitability" factor was explained based on the results of Fix and Lesniak (2017) in "Perspective on Coliving, Reimagining the Experiences, Processes, and Designs of Shared Living" which showed that one of the advantages provided by co-living occupancy is quality lifestyle such as equality (Fix and Lesniak 2017).

This, therefore, means the feeling of satisfaction factor in occupancy affects the feelings of residents such as the enjoyment obtained from having their desires and needs satisfied and some other factors found in previous studies.

Factor 5: Environment factor

Katz, N (2016) and Vestbro, DU and Horelli, L. (2012) in Ataman and Dino (2019) showed that the advantages of co-living occupancy from an environmental aspect include the ability to reduce the total area of land use, energy, and wastes produced per person by sharing the resources at a cost. It also decreases ecological and environmental damages caused by individualism, social stratification, and wasteful consumer habits (Ataman and Dino 2019). Therefore, the fifth factor was the Environmental Factor and was selected due to its relation to the use of energy by the residents.

1. The "energy sources due to shared or community resources" factor was based on the results of Walker (2017) that co-living occupancy is a sustainable lifestyle where the residents learn to share and create energy sources (Walker 2017; Ataman and Dino 2019).

2. The "reducing ecological costs and environmental damages through shared use" factor was based on the results of Katz, N. 
(2016) and Vestbro, D.U. et., al (2012) in Ataman and Dino (2019) that occupancy coliving has the ability to reduce the occupancy area, energy, wastes production per person through the use of shared resources (Ataman and Dino 2019). It also decreases the ecological costs and environmental damage caused by individualism, social stratification, and wasteful consumer habits (Osborne 2018; Walker 2017).

3. The "distribution of the energy used is made to be even for each occupant " factor was observed to be different from the data obtained from the questionnaire survey conducted by SPACE10, Anton, and Irene (2018) where payments for energy were reported to be made according to the quantity used per person (SPACE10, Anton, and Irene 2018). This research found the energy to be evenly distributed to all residents regardless of the quantity used.

This, therefore, means the co-living residents consider things related to the use of energy together in order to benefit from an economic point of view and avoid environmental damage.

Factor 6: Intrinsic factors

Cupchik, Ritterfeld, and Levin (2003) in Mulliner and Algrnas (2018) described intrinsic attributes to include house size, interior layout, design, and functionality, space, number of rooms, and internal design (Mulliner and Algrnas 2018). Therefore, it was considered the sixth factor in this research due to its focus on space arrangement in occupancy.

1. The occupancy equipped with furniture/full furnished is the choice of respondents and this was observed to be in accordance with the information provided by Fix and Lesniak (2017) that the desire to move to a new occupancy without owning anything and not having to buy a lot of household items is very attractive (Fix and Lesniak 2017). This was also observed to be the reason to live in a coliving residence for some people as reported in Osborne community (2018). This is, however, discovered to be different from the findings of SPACE10, Anton, and Irene (2018) that most respondents only want a shared area which is fully furnished while they have their private area (Osborne 2018; SPACE10, Anton, and Irene 2018).

2. Osborne (2018) showed the "design occupancy like a private apartment" factor to involve the design of co-living occupancy with private areas which are equipped with facilities such as beds and wardrobes, workstations, and private bathroom (Osborne 2018).

3. The occupancy preference for the type of site and clusters was found to be in accordance with the report presented by Ekananda and Marcillia (2019) which showed generations Y and $\mathrm{Z}$ in Yogyakarta prefer site-shaped housing. The same was also reported by Nadiya (2017) that the millennial generation in West Jakarta selects residential sites to live in and this further confirms the finding of this study that the respondents prefer grouped occupancy (Ekananda and Marcillia 2019; Nadiya 2017). However, Lachman \& Brett (2015) in Ekananda and Marcillia (2019) had different findings with the millennial generation discovered to prefer an apartment occupancy (Ekananda and Marcillia 2019).

This, therefore, means the intrinsic factor with the focus on the interior arrangement also affects the habitual behavior of the millennial generation in co-living occupancy.

\section{Factor 7: Extrinsic factors}

The attributes included in the extrinsic factors include the exterior design or building facades, quality of building materials, and the availability of green open space (Mulliner and Algrnas 2018). Therefore, extrinsic attributes were used as the seventh factor due to their focus on the arrangement of space outside the occupancy.

1. Ekananda and Marcillia (2019) indicated the "preference for housing with a garden" factor is preferred by generations $\mathrm{Y}$ and $\mathrm{Z}$ due to their desire for a dominant garden area in selecting a residence (Ekananda and Marcillia 2019). This was also supported by the findings of Wardhani, Sumarwan, and Yuliati (2016) that one of the things influencing consumer perceptions and preferences is the availability of a garden in each house as well as the residential concepts and designs (Wardhani, Sumarwan, and Yuliati 2016).

2. The "selection of occupancy based on the architectural design concept of the building" factor was found to be in line with the findings of Kanter (1972) in Green (2017) that physical design is a factor which influences the success and failure of the co-living housing model in practice (Green 2017). Moreover, Thomsen and Eikemo (2010) in "Aspects of student 
housing satisfaction: a quantitative study" also showed that students view the physical environment as an important factor to achieve satisfaction in temporary housing but considered less important in comparison with their preferences in permanent housing (Thomsen and Eikemo 2010; Tambunan 2009). Ekananda and Marcillia (2019) also showed that generations $\mathrm{Y}$ and $\mathrm{Z}$ prefer a contemporary architectural style with a combination of monochrome and analog colors for occupancy (Ekananda and Marcillia 2019).

The extrinsic factor or arrangement of the outer space in the occupancy has also been discovered to be one of the factors shaping the shared-living behavior of the millennial generation in co-living occupancy.

Factor 8: Group development factor

Residents tend to experience obstacles in the process of building bonds in society and the development process was grouped by Tuckman (1965) in Ruiu (2015) into 4 steps which are shaping, storming, norming, and performing (Ruiu 2015). Therefore, the group development factor was used as the eighth factor due to its relation to the possibility of developing the residents in the community.

1. The "potential for arguments between residents" factor was described by SPACE10, Anton, and Irene (2018) to be the occurrence of conflict between residents and observed to be one of the contradictory things occurring in co-living based on the information obtained from the respondents (SPACE10, Anton, and Irene 2018). These possible conflicts were, however, basically discovered to be one of the ways of strengthening the residents in the house. Meanwhile, Tuckman (1965) in Jarvis (2010); Ruiu (2015) in Lutfiyah and Herlily's (2019) "Participatory in Kampung's Cohousing Development: Learning from Kampung Muka, North Jakarta" showed the 4 stages of group development and one of them, storming, was found to be the stage where conflict occurs in the community (Jarvis 2010; Lutfiyah and Herlily 2019). This is usually followed by maturation and selection and later the performing stage where the rules would have been working effectively with more flexibility due to the increase in trust between the group members. This, therefore, makes it possible to achieve the group's function without conflict and become one unit.

2. The "sharing of sexisting facilities and equipment in the occupancy" factor is in line with the popular knowledge that co-living focus on reducing private space and increasing shared facilities (Osborne 2018). This means there are more opportunities for spontaneous interaction than people in private suites and this further improve intimacy among residents (McAlone 2016).

3. The "bedrooms for no more than 2 people" factor showed the respondents actually prefer not to share their personal facilities with most observed to be willing to share utilities, internet, garden, and workspace. Some do not want to share their bedrooms while some were observed not to be willing to share groceries and bathrooms (SPACE10 2017). This is in line with the findings that showed that the only reason the respondents are willing to share facilities is to reduce costs.

This, therefore, means the group development factors are majorly focused on matters related to the development of ties in society such as the reduction of quarrel potentials between the residents and collective use of goods. These are, however, discovered to be in line with the findings of previous studies on developing ties in the community.

Factor 9: Economic factors

Co-Living has the ability to reduce rental costs, and interact socially with other residents without any time and place restrictions and also allows saving more on budget by sharing rent. Therefore, economic factor was used as the eighth factor due to the desire for affordable prices by the residents.

1. The affordability factor: Massive urbanization has an impact on the high level of property ownership for the millennial generation. Therefore, co-living occupancy is considered a way to overcome this problem due to its advantages which is the provision of a quality lifestyle at an affordable price (Fix and Lesniak 2017); Lang, R. et al., 1990-2017 in Ataman and Dino (2019); and Hoppenbrouwer (2019). Therefore, consumers usually have a need before buying or making a purchasing decision but they are also stimulated from the outside as observed by Tambunan (2009) through several 
marketing stimuli such as price (B. Z. Putra and Rahayu 2015).

2. The "strategic location and proximity to public transportation" factor: Ekananda and Marcillia (2019) showed one of the ideal occupancy criteria for workers is easy accessibility (Wardhani, Sumarwan, and Yuliati 2016). Moreover, Thomsen and Eikemo (2010) in "Aspects of student housing satisfaction: a quantitative study" also indicated location as the most influencing factor in choosing a residence in Putra and Rahayu (2015); Fachrudin and Fachrudin (2014) also established the relationship between the environment, location of the boarding house, and the tenants as well as the boarding house, surrounding community, and building functions in achieving satisfaction.

The economic factors are, therefore, also one of the main objectives of living in co-living due to the desire of occupants to save rental budget and this is in accordance with the findings of previous studies as explained through the concept of affordability.

Factor 10: Workspace availability factor

SPACE10, Anton, and Irene (2018) showed workspace as one of the facilities not considered to be causing a problem when used together and the same was also discovered from the data obtained from the questionnaire where workspace was indicated to be a very important facility. Osborne (2018) also researched several co-living residences and found workspaces to be located in both public and private areas. It is well-known that one of the goals of co-living is to target young start-ups in the technology industry and entrepreneurs willing to collaborate (Walker 2017). Therefore, co-living needs to provide space for occupants to work or collaborate within the community (Osborne 2018).

This, therefore, means the availability of workspace is an important factor in shaping the behavior in co-living occupancy due to its focus on the younger generation in the technology industry.

\section{Conclusion}

This study aimed to determine and understand the factors shaping residential behavior in the coliving space among millennials in Indonesia through the use of Exploratory Factor Analysis (EFA). The factors found in this study including the formation of social factors, public facilities, social, place attachment, feeling of satisfaction, environment, learning, extrinsic, group development, economy, and availability of workspace are similar to the results of previous studies. This research is, therefore, expected to contribute to the understanding of the life-sharing behavior preferences for the millennials generation and become a reference for occupancy sector designers and developers.

\section{Suggestion}

1. The results of this study are based on a quantitative approach and the use of previous findings to corroborate or correct the findings. It is, however, recommended that future research to explore the factors influencing these behaviors are also studied qualitatively to determine new things on the feelings of occupancy, obtain more information, and confirm the results of this study.

2. Green (2017) in "The Logistics of Harmonious Co-living' showed the need for several experiments in co-living space models of different regions in order to determine the right settings to foster demographics and culture in a selected city. It is also recommended that further research use the probability sampling technique in the form of clustered or area sampling method to focus on one area of Indonesia. Meanwhile, a stratified random sampling method can be used to take the number of samples due to the uneven millennial population in each of the regions (Sugiyono 2019).

3. Ataman and Dino (2019) showed one of the targets of co-living space is architectural design. Therefore, further research should be conducted in the form of a new postoccupancy-evaluation in order to obtain responses on design solution from the occupants.

\section{References}

Ataman, C, and I Gursel Dino. 2019. 'Collective Residential Spaces in Sustainability Development: Turkish Housing Units within 
Co-Living Understanding'. IOP Conference Series: Earth and Environmental Science 296 (July): 012049. https://doi.org/10.1088/17551315/296/1/012049.

Badan Pusat Statistik. 2018. Statistik Gender Tematik: Profil Generasi Milenial Indonesia. Jakarta: Kementerian Pemberdayaan Perempuan dan Perlindungan Anak. https://www.kemenpppa.go.id/lib/uploads/list /9acde-buku-profil-generasi-milenia.pdf.

Ekananda, A. Nindyah, and Syam Rachman Marcillia. 2019. 'Preferensi Atribut Fisik Hunian Generasi Y Dan Z Di Yogyakarta'. In SMART \#4 - Seminar on Architecture Research \& Technology, 327-35. Yogyakarta: Universitas Kristen Duta Wacana. https://smartfad.ukdw.ac.id/index.php/smart/ article/view/119/103.

Fachrudin, Khaira Amalia, and Hilma Tamiami Fachrudin. 2014. 'Tenant Satisfaction in Boarding House and Its Relationship to Renewal in Medan City, Indonesia'. International Journal of Academic Research 6 (2): 97-101. https://doi.org/10.7813/20754124.2014/6-2/A.16.

Fauziyyah, Alya, and Sutarimah Ampuni. 2018. 'Depression Tendencies, Social Skills, and Loneliness among College Students in Yogyakarta'. Jurnal Psikologi 45 (2): 98. https://doi.org/10.22146/jpsi.36324.

Fix, Ryan, and Matthew Lesniak. 2017. Perspectives on Co-Living: Reimagining the Experiences, Processes and Designs of Shared Living. New York City: PUREHOUSE LAB. https://coliving.pressbooks.com/chapter/thepresent-and-future-of-co-living-typologiesand-business-models/.

Green, George. 2017. 'The Logistics of Harmonious Co-Living. Exploring Contemporary Co-Living through Design Interventions.' Linnaeus University. http://Inu.diva-

portal.org/smash/get/diva2:1112614/FULLT EXT01.pdf.

Hoppenbrouwer, Bas. 2019. 'The Community Effects of Co-Living: Exploring Opportunities for Dutch Developer-Led Co-Living in Fostering Community Building among Residents' Radboud University. https://theses.ubn.ru.nl/bitstream/handle/1234
56789/8521/Hoppenbrouwer,_Bas_2.pdf?seq uence $=2$.

Jarvis, P. 2010. Adult Education and Lifelong Learning: Theory and Practice. New York: Routledge.

Johnson, Cat. 2016. 'New Guide Explores the Past and Bright Future of Coliving'. SHAREABLE: People-Powered Solutions for the Common Good. 2016. https://www.shareable.net/new-guideexplores-the-past-and-bright-future-ofcoliving/.

Lutfiyah, Dinda, and Herlily Herlily. 2019. 'Participatory in Kampung's Co-Housing Development: Learning From Kampung Muka, North Jakarta'. CSID Journal of Infrastructure Development 2 (1): 74. https://doi.org/10.32783/csid-jid.v2i1.43.

McAlone, Nathan. 2016. 'The Truth about the "Dorms for Adults" That \$16 Billion WeWork Is Betting Its Future'. Business Insider. 2016. http://www.businessinsider.com/co-livingstartups-turn-normal-2016-7.

Mulliner, Emma, and Mohammad Algrnas. 2018. 'Preferences for Housing Attributes in Saudi Arabia: A Comparison between Consumers' and Property Practitioners' Views'. Cities 83 (December): $152-64$. https://doi.org/10.1016/j.cities.2018.06.018.

Nadiya, Elzsa. 2017. 'Studi Preferensi Generasi Y Dalam Memilih Hunian Di Jakarta Barat'. Jurnal Muara Ilmu Ekonomi Dan Bisnis 1 (1): 145. https://doi.org/10.24912/jmieb.v1i1.417.

Najib, Nurul Ulyani Mohd, Nor Aini Yusof, and Zulkifli Osman. 2011. 'Measuring Satisfaction with Student Housing Facilities'. American Journal of Engineering and Applied Sciences 4 (1): 52-60. https://doi.org/10.3844/ajeassp.2011.52.60.

Osborne, Rachel. 2018. 'Best Practices for Urban Coliving Communities'. University of Nebraska - Lincoln. https://digitalcommons.unl.edu/arch_id_these $\mathrm{s} / 16 /$.

Pramudito, Sidhi, Antonius Lanang Tegar Wicaksana Praptantya, and David Jeffry Nasir. 2019. 'A Study of Vertical Dwelling Design Model Based on Community Interaction in Winongo Riverbank Yogyakarta'. ARTEKS: Jurnal Teknik Arsitektur 3 (2): 171-86. https://doi.org/10.30822/arteks.v3i2.68.

Putra, Bagus Zakarya, and Sri Rahayu. 2015. 'Faktor-Faktor Yang Mempengaruhi 
Pemilihan Perumahan Dan Tipe Rumah Di Perumahan Bukit Emerald'. Jurnal Teknik $\begin{array}{llll}P W K & 4 & \text { (4): } \quad 681-91 .\end{array}$ https://media.neliti.com/media/publications/2 13472-faktor-faktor-yang-mempengaruhipemiliha.pdf.

Putra, Yanuar Surya. 2017. 'Theoritical Review: Teori Perbedaan Generasi'. Among Makarti 9 (2). https://doi.org/10.52353/ama.v9i2.142.

Rubinstein, Robert I., and Patricia A. Parmelee. 1992. 'Attachment to Place and the Representation of the Life Course by the Elderly'. In Place Attachment, 139-63. Boston, MA: Springer US. https://doi.org/10.1007/978-1-4684-87534 -7.

Ruiu, Maria Laura. 2015. 'The Effects of Cohousing on the Social Housing System: The Case of the Threshold Centre'. Journal of Housing and the Built Environment 30 (4): 631-44. https://doi.org/10.1007/s10901-0159436-7.

Sanjaya, Wisnu A., and Rumiati Rosaline Tobing. 2019. 'Modular Low-Cost Vertical Housing Benefit from Using Prefabricated Cross Laminated Timber Panel'. ARTEKS : Jurnal Teknik Arsitektur 3 (2): 199-214. https://doi.org/10.30822/arteks.v3i2.70.

Santoni, Fransisca Yongsie, and Evian Devi. 2020. 'Analisis Kondisi Lingkungan, Bangunan Dan Tempat Rekreasi Lansia Pada Panti Jompo, Studi Kasus: Sasana Tresna Werdha Karya Bhakti Ria Pembangunan Dan Panti Werda Wisma Mulia'. ARTEKS : Jurnal Teknik Arsitektur 5 (2): 205-18. https://doi.org/10.30822/arteks.v5i2.380.

SPACE10. 2017. 'Central Saint Martins + SPACE10: Exploring Shared Living'. 2017. https://space10.com/central-saint-martins/.

SPACE10, Anton, and Irene. 2018. 'How Will We Live in the Year 2030?' ONE SHARED HOUSE 2030.2018. http://onesharedhouse2030.com/results/.

Subroto, Tarcicius Yoyok Wahyu. 2019. 'Koeksistensi Alam Dan Budaya Dalam Arsitektur'. ARTEKS: Jurnal Teknik
Arsitektur 3 (2).

https://doi.org/10.30822/arteks.v3i2.60.

Sugiyono. 2019. Metode Penelitian Kuatintatif, Kualitatif Dan R\&D. Alfabeta. 2nd ed. Bandung: Alfabeta. https://doi.org/2008.

Tambunan, Damelina B. 2009. 'Atribut Yang Menjadi Pertimbangan Konsumen Dalam Membeli Produk Perumahan Penelitian Dan Analisis Conjoint'. International Research Journal of Business Studies 2 (2): 141-53. http://irjbs.com/index.php/jurnalirjbs/article/v iewFile/37/37.

Thomsen, Judith, and Terje Andreas Eikemo. 2010. 'Aspects of Student Housing Satisfaction: A Quantitative Study'. Journal of Housing and the Built Environment 25 (3): 273-93. https://doi.org/10.1007/s10901-0109188-3.

Walker, Jodie. 2017. 'Co-Living'. THE SECRET AGENT REPORT 59: 3-6. http://secretagent.com.au/wpcontent/uploads/2017/09/The-Secret-AgentReport-Sep-2017-CoLiving.pdf.

Wardhani, Widya, Ujang Sumarwan, and Lilik Noor Yuliati. 2016. 'Pengaruh Persepsi Dan Preferensi Konsumen Terhadap Keputusan Pembelian Hunian Green Product'. Jurnal Manajemen Dan Organisasi 6 (1): 45. https://doi.org/10.29244/jmo.v6i1.12183.

Widodo, Johannes. 2019. 'Human, Nature, And Architecture'. ARTEKS: Jurnal Teknik Arsitektur 3 (2): 145-48. https://doi.org/10.30822/arteks.v3i2.65.

Williams, Jo. 2005. 'Designing Neighbourhoods for Social Interaction: The Case of Cohousing'. Journal of Urban Design 10 (2): 195-227.

https://doi.org/10.1080/13574800500086998.

\section{Author(s) contribution}

Isrina Indah contributed to the research concepts preparation, methodologies, investigations, data analysis, visualization, articles drafting and revisions.

Prabu Wardono contribute to the research concepts preparation and literature reviews, data analysis, of article drafts preparation and validation. 
ARTEKS : Jurnal Teknik Arsitektur, Volume 6 Issue 2, August 2021

pISSN 2541-0598; eISSN 2541-1217 